\title{
The Characteristics of Romanticism in the Children's Poem in Iran
}

\author{
Ali Armaghan (Corresponding author) \\ Faculty of Letters and Humanities, Kashan University, Kashan, Iran \\ E-mail: Aliarmaghan70@yahoo.com \\ Reza Shajari \\ Faculty of Letters and Humanities, Kashan University, Kashan, Iran \\ E-mail: rshajari@yahoo.co.uk \\ Maryam Jalali \\ Faculty of Persian language and literature, Shahid Beheshti University, Tehran. Iran \\ E-mail: ma_jalali@sbu.ac.ir \\ Alireza Fouladi \\ Faculty of Letters and Humanities Kashan University, Kashan. Iran \\ E-mail: Fouladi2@yahoo.com
}

Doi:10.7575/aiac.alls.v.7n.5p.59

Received: 04/05/2016

URL: http://dx.doi.org/10.7575/aiac.alls.v.7n.5p.59

Accepted: 16/07/2016

\begin{abstract}
Romanticism is one of the important contemporary literal schools and has absorbed many poets and authors all across the world. Persian literature specifically the adolescents and children poem in Iran has been affected. Many Iranian poets have been among the pioneers of romanticism in the adolescents and children poem. The poems of these poets include delicate interpretations and concepts in the principles of romantic poem. They have used the specifications and principles of romanticism due to the conditions and outlook of the addressees (children and adolescents). The current essay scrutinizes the characteristics of romanticism in the adolescents and children poem. Romanticism considers identifications such as naturalism, rustic are tendencies, liberalism, nostalgic issues, individualism and tendency to traveling. It also tries to explore new interpretations.
\end{abstract}

Key words: contemporary poem, Iran, adolescents and children poem, romanticism

\section{Introduction}

All Persian literature is much different from the west literature and it is not possible to apply all the special concepts and expressions of west literature in the Persian one. Moreover, all the European schools and movements don't have proper equivalences in Iranian culture and literature (Jafari, 2007:11). There are Persian contemporary literary works and movements coped with the western ones.it should be considered that some of the western concepts and movements have been also affected from the east. 'Although renaissance has been risen from the very depth of medieval time and greatly affected by ancient Greek and Rome, it has never been identified one dimensional phenomenon and purely western. Medieval time and the events of renaissance in contrast to Ottoman emperorship are considered as two factors against Islam which have profoundly affected west.'’(Servat, 2006:63)

Romanticism is among the school which has always been presented in the contemporary Persian poem and the poets have been using it.

In one of his Pose works, Shahriyar points out that romanticism was first entered to Iran through romantic stories and drew the attention of poets and writers. Also, Shahriyar in this prose published in his Divan: 'An Introduction Greatest Men of the World and Iran' - introduces Mirza Jafar Khamenei as one of the pioneers of employing imagination and romantic fantasy in Iran, an imagination which completed in Nima's fiction (Sadrinia, 2005: 135). Elsewhere, Mizade Eshghi, the contemporary revolutionary poet, has been introduced as the romanticism pioneer in Iran (Modarresi, 2012:22).

It seems that romanticism has been used more than other western literary schools and remarkably influenced the children and adolescents poems. These characteristics will be scrutinized in the current essay. 


\section{Review of Literature}

Although there are many essays and books on the effect of romanticism in Persian adult's poem, no specific research has been written to figure out the influence of western schools and movements on children and adolscents poem. This essay is the first research in this regard.

Within the last century, more than 100 poem books have been published for adolescents and children which the specifications of romanticism has been extracted from. Some of them are introduced as below:

\subsection{Naturalism}

Jan Jack Russo believed that romanticism is moving back to nature (Forest, 1996:13). Naturalism is identified as the basis in of children and adolscents poem of Iran; the unity between human and nature is very common in the romantic verse and prose and even painting, specifically, in situations in which the natural environment resembles to the man's spirit and mind condition (1996:13). This is more comprehensible while reading some poems and pieces of writing written for children and adolescents. This becomes more understandable and the unity of the poet with the nature and its components and elements is observed more clearly. Describing a stormy day, Ebrahimi starts the introduction of one of his poems, Willows:

Some Willows are standing in wind at the middle of the alley

Like some women, they're taking

Wind leaves apart their leaves

Wind tenderly combs their hair

The horse of wind scream

The air gets dusty

A child escapes a corner

From this intensive wind

Suddenly, one of the Willows is broken and bent

$\mathrm{Oh}$, the Willows are again standing in wind

It falls off and the alley pathway is obstructed

Like some women

They are mourning (Ebrahimi, 2010:75).

In this poem, the nature is ready to give hand and train human (2010:196). This is the concept that the British romantic poet-critics have obtained; it means to indirectly train the poem. "Wherever, he goes, carries a burden of love and kindness and he expands the board of human sensitivity" (Harland, 2014: 131). Nurturing the imagination and making the addressee to think implies the poet's naturalism. Among romantic theorists, who one had tendencies to nature and imagination in poem and considered it as the main art source; he also believed that power of imagination affects the poet the most in the poem (Wellek: 1998:78). In the following poem the poet likes to be accompanied with nature and the deserved behavior of the poet is the one animated from nature.

I desire to fly with the ducks

Like an old turtle

I am patient (Aminpur, 2009: 63)

In another poem, he calls out spring as the symbol of nature to decrease his romantic grief:

Call the spring

From out the village hills

To feel the smell of flowers

Call the spring

Because the village ambiance is dismal

Sadness is everywhere all through the fog (Ebrahimi, 1992 :22).

from 1986 to 1999 , this poet composed 262 poems which 99 of them were about nature; meaning that 37.09\%of them are devoted to nature(Kashefi Khandari, 2001:1030) and this percentage is remarkable among all various subjects that a poet may consider them.

\subsection{Rustic tendencies}

One of the features of naturalism is to tending to village and simple life. The romanticism interprets village in contrast to city and minds it the symbol of human natural life and innocence. This is while, city pictures the artificial life made by civilization and cruelty. Hence, city is described by deception and violence. William Copper (1731-1800) explains this romantic concept of village and city: 'God created village and the man created city (2003:145). 
Jean-Jacques Rousseau considered the contrast between individual and society before W. Blake and believed that the only alternative is to go to natural life. He stated that: human used to live in peace in nature and there were no convention. He doesn't suffer from hers. He had a strong body and he was very smart. Rousseau believes that this native wild was good in nature a civilization assessing everything with materialistic criteria (Khosrownezhad, 2013:52). Some of the Iranian children and adolescents consider village like that; they believe that all moments of it are pure and magnificent and human is full of conscious there and close to his nature. The village soil smells like kindness and flower and its skies smiles at human," village is like an Utopia in their poem, not like the one for philosophers in far future; this Utopia is situated somewhere in a close past; a past in which the poet has lived in and is nostalgic about (SeyyedAbadi,1994:11) One Ebrahimi's poems on village is as below:

When Hanna goes to the city farm/ calls both the grandmother and farm (2008:165)

These items are rooted in the memories of childhood and regarded as the poet's nostalgic description; however, the poet remembers the village all like this.

Naturalism usually ends to village. The rustic essence is prominent characteristic of such poems. Even poems not directly connected to village, the rustic nature is the building block of the poem. In fact, the poet reviews his lovely memories and remembers village like a paradise abandoned from someone (KashefiKhansari, et al, 2001:85).

In contrast to village, some poets greatly define city and describe city as the symbol of modernity just like the romantic poets.

\subsection{Individualism}

Individualism is identified as one of the characteristics of the romantic poems of the children and adolescents poets in Iran. These poets use "I" as the first point of view the most. Plural point of view and pronouns are used the least. This can be interpreted as perishing and trusting and giving self- confidence to the children and adolescents as addressee.

Oh, Love. I have been the captive of your game/ it has been a long time I have been addicted to your game/ you shaped me in the way you wanted./

It seems as if I am the paste of your game (SafarBeigi, 2010: 52)

As it is clear, 'I'" is the representative of the community of the children and adolescents which is true in other poems.

\subsection{Sensitivity}

The poets of the children and adolescents believe that poem ids a success to express feelings, they consider poem as an effective and successful means to define the realistic inner emotions of the poet. They don't want to induce a concept or poetic features to their addressee but to convey love and affection.

Some of the poems are actually childish proses and images are found the least. The poetic elements are usually found as emotions and harmony in addition to narration increasing the range of imagination:

Knocking sound/ Dad arrived in/I opened the door/ I found happiness (Rahmandust, 1999:3)

\subsection{Nostology}

Berlin (1909-1997), an intellectual and political theorist, believes that romanticism is nostology; it is like hanging on imagination; it is a pacifying dream, a sweet and dark illusion (Berlin, 2008). It is like retelling the lost ambiguous memories. It is accompanied with nostology and desire. These parameters are remarkably observed in romantic poems of different countries and most of the romantic poets have used the nostalgic memories (Jafari, 2007; 262)

The outlook of the poem of some the children and adolescents poets reveals a nostology to the past; a nostology which is devoted to the poet and might have nothing to do with the addressee, In this poem, the poet misses and desires his brilliant and simple childhood world, the games and the nature of his residential area. The poet feels something like grieving while recalling these ling lost childhood memories and donates a mythological inspiration to his magnificent childhood memories. Myth is part of the childhood life and it holds the childhood desires (Abraham, 1998: 104). The poet has given a mythological ambiance to his childhood in the following

Every step of it/ is a marvelous story/ a good memory/ from our childhood (Rahmandust, 1990:20)

This poem is the type of poem that not only implies a nostology but also makes the addressee think about his past and it accompanies him up to the plant life he imagines for himself. He recalls patterns like the goat in myths, a sacred animal symbolizing reproducing and bonus (Gholizadeh, 2013:78) he also recalls apple which implies perfection and earthy desires or giving them (Sarlue Khan,2010).

\subsection{Freedom}

Freedom is identified as one of the fundamentals of romanticism. The romantic artist believes that love and affection inspires him the concept and meaning of life. This love and affection should be free (SeyyedHoseini, 2012/180:1).

Rousseau is known as one of the prominent figures in the freedom literature. In his famous book, Emil, he advises the teachers like this: " let the child feels that he is the one that the control is in his hand although it is you are controlling everything. He recommends that the child must believe that he is free and he should feel freedom. Sometimes, we observe symbols of freedom in the poem of this poet which cannot be actually interpreted as the concept of freedom or it can't be defined for the child as his addressee is it might be accompanied by ambiguity like freedom in the poem below: 
I am a tree/ green and happy/ I am tall/ I see everything around me from here/ there is a mountain/ in front of me/ and dessert is under me/ my feet are rooted into the earth/ and my head high above/ I am free from my sadness and sorrows (Ebrahimi, 1986:16)

It is wind/ it wanders/ it is free/ it hits the leg/ it sweeps the dust/ from the plain (Rahmandust, 1990: 35).

Being free has been mixed with being happy; however, comprehending the meaning of the poem might be ambiguous for the addressee. The addressee can't realize if the reason of being free is to be free of sadness or the reason of releasing from sadness is freedom.

\subsection{Travel}

Since, the annoyance of the real world directs us to travel through history and geography, real travel or traveling on the wings of imagination is identified as one of the specifications of romanticism (SeyyedHoseini, 2012/1:181). These types of the poets' poems can be regarded an example of the effects of romanticism on his mind and language. So, the poems are divided into two types in the books of children and adolescents: imaginary travels to geographical places and traveling through history. In many cases, the poem is a means for the poets of the children and adolescents; it is like an instrument to escape from the real world and move into the imaginary travel and to report a real and geographical travel. In geographical travels, the poet usually travels to nature and natural resorts which are full of magnificent beauties and traveling to such places can be a wish for the addressee like traveling to mountains, valleys, plains or even travel to sky and moon. In the books considered so far, poets' travels are almost imaginary and the poet indirectly reports his own imaginary travel. However, he sometimes travel to places where they can have good traits; In the Sky is identified as a symbol of perfection, it is like the remotest destination presenting symbols for being anonymous and purity. The land of lights reminds clearance and honesty. In historical travels, the poets of the children and adolescent's poem of Iran travel through time. These poems are very few.

\subsection{Attempting to explore new concepts and interpretations}

The romantic artist explores his minds and tries to explore the unknown things (Pakbaz, 1975:22). In the book of literary terms, these characteristics are regarded as explorations and evidences and remarked as the principles of romanticism ( SeyyedHoseini, 2012/1:182). Children poem in Iran doesn't go back to long ago to be affected by the traditions. Hence the poets of children and adolescents poems should always look for new spaces and they try for this purpose. However, it is expected that the reader of these poems try to explore and comprehend the issues and relationships between objects.

\section{Conclusion}

Like science and technological movements, literary and cultural movements have been moving and move from one land to another and they affect or affected. Romanticism is identified as the western literary movements meaningfully influenced the Persian poem. Due to the social conditions of the present society of Iran and the wide range of romanticism aspects and definitions, the contemporary poem has been greatly affected from. Poets as the composer of the children and adolescents poems have unconsciously accepted this trend. Some of the romanticism aspects are observed in high frequency in his poem. Romantic poets are naturalism and natural symbols and elements are very outstanding in their poems. From romantic point of view, the poem of the children and adolescents poets point out to tendencies to village life, liberalism, nostology, sensitivities, individualism, tourism and also attempting to explore new concepts and interpretations.

\section{References}

Abraham, K, (1998). Dreams and myths; a study in race psychology, translated by Jalal Sattari, Tehran: Markaz.

Aminpur, G. (2009). Sudden Mirrors ( ayenehaye naghahan), Tehran: Ofogh

Berlin,A. (2008). The Roots of Romanticism, translated by Abdollah Kowsari, Tehran: Mahi Publication.

Ebrahimi, J. (1998). Water like hello (Ab mesle salam), Tehran: the publication of the training and nurturing center of children and adolscents.

. (1992). The smell of the sparrow (Buye gonjeshk), Tehran: the publication of the training and nurturing center of children and adolscents.

(1976). Blossoms of poem(ghonchehaye sher), Tehran: the books of Shokufeh related to Amir Ksbir Publicaqtion.

(2010). Moments in poems, poem in moments (Lahzeha dar sher, sher dar lahzeha), Tehran: The Institute of Ghalam Community of Iran.

Forest, L. (1996). Romanticism, translated by Masud Jafari Jozi, Tehran: Markaz

Gholizadeh, K. (2013). The mythical encyclopedia of animals and related terms( daneshnameye asatirie janevaran va estelahate vabasteh), Tehran: Parseh Book.

Harland, R. (1993). Literary Theory From Plato to Barthes: An Introductory History, translated by Sharpur Jorkesh and Ali Masumi, Tehran: Cheshmeh.

Hosein Khani, H. (2009). From this parallel paradise, Tehran:Taka. 
Khosrownezhad, M, (2013). Innocence and experience (Masumiat va tajrobeh), An introduction to the philosophy of the child literature, Tehran: Markaz.

Kashefi. K., and Pakaeen, P. (2001). Figures of children and adolscents literature (chehrehaye adabiate kudakan va nojavanan), Tehran: Ruzgar.

Modarresi, F., \& Samadi, A. (2012). The effect of romanticism on Mirzadeh Eshghi's works (tasire romanticism da asare Mirzadeh Eshghi, Literary terms publications, Isfahan University, Fourth year, No: 2, autumn and winter.

Pakbaz, R. (1975). An artistic and social study on Impressionism, Tehran: Roz Publication.

Rahmandust, M. (1999). Blue Alleys(Kuchahaye Abi), Tehran: Mehrab Ghalam Publications.

. (1990). Dad came, he brought bread(Baba amad, Nan avard). Tehran: the publication of the training and nurturing center of children and adolscents.

Sadrinia, B. (2003). The symbols of Romanticism in Shahryar's poems(Jelvehaye romanticism dar shere Shahrryar), The publication of the faculty of literature and humanities of Tabriz University, Fourth and Sixth year.

SafarBeigi, J. (2010). Nothing(Hich), Mashhad: Sepideh Barun.

Sarlue Khan. E. (2010). The dictionary of symbols, translated by Mehrangiz Ohadi, Tehran: Dastan.

Servat, M. (2006). An Introduction to literary schools (Ashnaee ba maktabhaye adabi), Tehran: Sokhan.

SeyyedAbadi, A. A. (1994), One point, one book(Yek nokteh, Yek ketab), publication of the Sureye Javanan, No:71,p11. SeyyedHoseini, R. (2012). literary schools (Maktabhaye adabi), Tehran: Agah.

Skinner,B.F. (1975). Beyond freedom and Dignity, translated by Mohammadi. Tehran: Agah.

Wellek, R. (1998). A History of Modern Criticism, translated by Mojtaba Abdollahnezhad, Mashhad: Mohaghegh. 